\title{
Spirillary rat-bite fever
}

INSERM

\section{Source}

INSERM. (1999). Orphanet: an online rare disease and orphan drug data base. Spirillary rat-bite fever. ORPHA:99903

Spirillary rat-bite fever (RBF), also known as Sodoku (Japanese for so: rat and doku: poison), is caused by the Gram-negative bacillus Spirillum minus and is transmitted to humans through the bites and scratches of rats. The disease is mostly present in Asia. 